УДК 321.01:659.3

DOI https://doi.org/10.32837/apfs.v0i29.967

\author{
В. I. Ломейко \\ ORCID ID: https://orcid.org/0000-0002-4777-3444 \\ аспірантка кафедри політичних теорій \\ факультету психологїі, політології та соиіологї \\ Національного університету «Одеська юридична академія»
}

\title{
ПОЛІТИЧНИЙ ПОРЯДОК ДЕННИЙ: «ІЕРАРХІЯ» VS. «МЕРЕЖА»
}

Постановка проблеми. Процес формування політичного порядку денного сучасного суспільства зітканий 3 протиріч. Їх можна знайти у боротьбі за панування у дискурсивному просторі між владою та опозицією, управлінською діяльністю (урядування/адміністрування) політиків та електоральними змаганнями, постійними конфліктами та намаганням знайти консенсус. Порядок денний створюється на перетині політичних інтересів та повсякденного знання, традицій конфлікту та консенсусу, на нього впливають штучні інформаційні спецоперації політичних лобістів та природний хід подій. Нарешті, з методологічної точки зору дослідник вибирає критичний дискурс-аналіз або постмодерний дискурс-аналіз для визначення сутності та наслідків інформаційного впливу. У цій статті увагу буде зосереджено на ще одній бінарній опозиції: «мережа» versus «iєрархія». Це протиріччя стосується впливу на формування політичного порядку денного з боку вертикально підпорядкованих структур («ієрархія») або неформальних нетривалих зв'язків горизонтального характеру («мережа»). До перших належать держава, політичні партії та традиційні медіа. До других - організації громадянського суспільства та соціальні мережі.

Саме явище політичного порядку денного $\mathrm{e}$ осердям сучасної політики. Боротьба за право та можливість впливати на процес встановлення політичного порядку денного зумовлює темп $\mathrm{i}$ характер сучасного політичного процесу. Фундаментальним положенням теорії порядку денного $€$ таке: «...громадяни мають справу з реальністю другого ґатунку, структурованою журналістськими звітами про певні події чи стан справ» [6, с. 27]. За іншим визначенням, політичний порядок денний, «...відбуваючись фактично у віртуальному просторі, здійснює реальний вплив на вибір людини... $\mathrm{y}$ найширшому плані порядок денний - це набір актуальних для суб'єктів питань, які потребують обговорення» [5, с. 212].

Аналіз останніх досліджень i публікацій. Засновник теорії настановчості (порядку денного) Максвел Мак-Комбс наголошує, що «...теорія настановчості далека від сприйняття аудиторії як автоматів, які тільки й чекають, щоб їх запрограмували новинні медіа. Але настановчість медій відводить ключову роль новинним медіа в ініціюванні суспільної програми - переліку тем, які суспільство вважає найважливішими. Або, перефразовуючи В. Ліпмана, подана в новинах інформація відіграє ключову роль у конструюванні нашої картини реальності. Більше того, вся інформація, яку подають новинні медіа, впливає на цю картину» $[6$, с. 34$]$.

Вітчизняний досвід формування політичного порядку денного грунтовно досліджено у працях В. Андрусіва, О. Демянчука, В. Ковалевського, В. Кулика, Г. Почепцова, Д. Яковлева. У статті «Битва за порядок денний» В. Андрусів зазначає: «Політичний порядок денний є стрижнем, навколо якого обертається вся політика. Увага, зусилля, боротьба і рішення політичних сил точаться навколо його ключових питань... Тому фактично той, хто контролює порядок денний, контролює всю політику» [1]. Він окреслює роль влади та опозиції у процесі формування політичного порядку денного в Україні, наводить приклади медіаскандалів, які покликані відвернути увагу суспільства від реальних проблем завдяки штучно створеним медіаподіям. О. Демянчук наголошує на важливості критичного мислення та політичної освіти задля уникнення пасток штучного формування порядку денного та маніпуляцій ним. Варто погодитись із тим, що «...для довготермінового успіху будь-якої публічної політики необхідна підтримка iї принципів і заходів населенням, а отже, спосіб залучення громадян до цього процесу та його наслідки для суспільства визначатимуться характером політичної системи та її взаємодією з різними суспільними групами» [2, с. 71].

У працях В. Ковалевського наголошується на значному потенціалі теорії порядку денного для України: «Складність та неоднозначність політичної ситуації у сучасній Україні спонукає дослідників до пошуку нових інтерпретаційних моделей та пояснювальних матриць. Однією з таких матриць $\epsilon$ схеми, що представлені новітніми підходами медіадосліджень. Саме вони нині намагаються пояснити ті складні процеси, що відбуваються у політичному полі навколо здобуття та реалізації влади» [5, с. 211-224].

Саме цей автор одним із перших відзначив дихотомію процесу формування політичного 
порядку денного. Він вказує: «Певна дихотомія вказаних процесів полягає у тому, що встановлення порядку денного відбувається з боку влади та з боку інших суб'єктів, які нині можуть цілком розглядатися теж як владні актори (наприклад, корпорації). В цьому плані цікавим видається розставлення акцентів в описі сучасних інформаційних процесів за допомогою методу встановлення порядку денного... У найширшому плані порядок денний - це набір актуальних для суб'єктів питань, які потребують обговорення. Він Iрунтується на таких постулатах: 1. Новинний порядок денний визначає публічний порядок денний (новина про подію визначає її обговорення). 2. Ми звертаємося до ЗМІ для того, щоб зрозуміти, на чому нам потрібно зосередити свою увагу (фокусування уваги для визначення, що важливого відбувається навколо). 3. Медіа не говорять нам, ЩО думати, вони кажуть нам ПРО ЩО думати (розставлення акцентів). 4. Нарешті... тепер медіа вже кажуть нам, що робити [5].

У працях Д. Яковлева [7; 8] реконструйовано процес формування політичного порядку денного та визначено політичні дебати як дієвий механізм раціоналізації політичної комунікації загалом та встановлення порядку денного зокрема.

Він зазначає: «У сучасному світі політичні комунікації опосередковані насамперед діяльністю масмедіа. Можна говорити про те, що у сучасній політиці з'являється нова потужна дійова особа - медіакратія, яка отримує можливість конструювати порядок денний та використовувати політичну комунікацію як інструмент реалізації влади. Це призводить до того, що за вплив на громадську думку конкурують теми, які з'являються у масмедіа... структура медіареальності цілком визначається оперативними правилами та організаційною рутиною, яким підпорядковані працівники масмедіа. Наявні цілі задають журналістам рутинні норми діяльності та визначають їх підхід до будь-якої події. Їх цікавлять тільки ті події, які можуть бути легко витягнуті з контексту, перетворені в історії і подані у супроводженні (якщо йдеться про телебачення) відеоряду. Саме вони і стають медіаподіями» [8].

Фактично медіаформат поглинув політику (передусім, у сенсі публічного адміністрування, або “public policy”), підпорядкував їі та трансформував у відповідності до вимог телевізійних шоу, інтернет-комунікацій та медіаскандалів. Єдиним шляхом протидії медіатизації політичного порядку денного є повернення до формату раціональних політичних дебатів. Майданчиком для таких дебатів історично був парламент. Саме тому необхідно повернутись до парламентських дебатів. Вони й мають визначати політичний порядок денний у демократичному суспільстві, а не масмедіа чи медіатизовані політичні інститути.
Відзначимо: «Провідна роль у формуванні простору демократичної політики належить парламенту, депутати представляють інтереси відповідних політичних, соціальних і регіональних груп. Роль парламенту як політичного інституту полягає, серед іншого, у формуванні простору дискусій, діалогу на основі представництва структурованих груп інтересів на державному рівні. При цьому парламент стає не просто дискусійним майданчиком, він має досить важелів впливу для прийняття законів та контролю за їх реалізацією, виконувати функції творення раціональної політики на основі аргументативної дискуciï» [8, с. 52]. Таким чином, виокремлюється ще одна дихотомія «медіатизація - раціоналізація» у процесі дослідження процесу формування політичного порядку денного. Водночас визначенню у цьому процесі ролі політичних «ієрархій» (владної вертикалі) та політичної «мережі» (горизонтально організованих взаємодій) у вітчизняному науковому дискурсі приділяється не досить уваги.

Мета статті - дослідити роль «ієрархії» та «мережі» у процесі формування політичного порядку денного.

Виклад основного матеріалу дослідження. Порядок денний суспільства є публічним і це одна із причин значного впливу масмедіа. На відміну від порядку денного індивіда та окремих соціальних груп, які можуть бути прихованими, або й утаємниченими. Наприклад, порядок денний номенклатури за радянських часів або олігархії у сучасних умовах. Характеристики політичного процесу визначаються публічним порядком денним, а політичні режими відрізняються, серед іншого, структурою його формування. Залежно від спрямування процесу створення порядку денного можна говорити про демократичний або авторитарний політичні режими. Для авторитарного політичного режиму характерною ознакою виступає вертикальна спрямованість формування публічного порядку денного: тут інформація рухається «зверху - вниз». Державний апарат нав'язує суспільству теми порядку денного, які найбільш вигідні саме для влади. Навпаки, демократичний політичний режим характеризується рухом інформації, делегуванням повноважень та формуванням порядку денного «знизу - вверх». Політичний процес в умовах демократичного політичного режиму відзначається постійним впливом соціальних груп на встановлення публічного порядку денного. Суспільство делегує повноваження, а влада зобов'язується виконувати накази спільнот. У цій взаємодії відбувається формування порядку денного. Можна стверджувати, що за демократії переважає суспільний інтерес у встановленні публічного порядку денного, а в умовах авторитаризму пріоритет належить приватним інтересам, які завдяки маніпуляціям 
з інформацією видаються за суспільний. I якщо раніше рейтинг важливих тем порядку денного за авторитаризму встановлюється завдяки контролю держави над медіа (наприклад, "радянська» та «пострадянська» моделі), то у сучасних умовах держава поступається ефективності власникам медіакорпорацій, які формують правлячий клас медіакратію. Саме тому нині говорять про загрози «інформаційного авторитаризму». Справді, «...у процесі комунікаційної взаємодії у сучасну добу, яка характеризується змінами традиційних форм та механізмів панування й трансформаціями політичних інституцій, з'являються нові небезпеки для демократії. Як одна з небезпек або один із викликів демократизації розглядається процес медіатизації політики, що потенційно несе у собі загрозу появи нової форми тоталітарного панування - інформаційного» [8].

Загалом, на процес встановлення порядку денного зростає вплив масмедіа. Але це не означає, що «мережа», умовно кажучи, перемагає «ієрархію». Навпаки, вертикально організовані медіакорпорації посилюють свій вплив на формування глобального (загальносвітового) порядку денного. Для України дослідження кейсу щодо встановлення порядку денного може стати одним із аргументів щодо впровадження санкцій проти олігархів [4].

Навіть у соціальних мережах, які десятиліття вважались осередком формування незалежної думки та прикладом горизонтальної взаємодії і впливом фактором кольорових революцій, посилюється цензура та вплив керівництва на визначення політики. Через блокування у соціальних мережах екс-президент США Д. Трамп навіть почав говорити про створення власної мережі [3]. Сучасні медіа не лише «посередники» між владою та суспільством у формуванні порядку денного. Вони володіють усіма необхідними технічними засобами та комунікативними технологіями задля конструювання порядку денного та підміни суспільного інтересу власними приватними інтересами. Про це свідчать такі терміни, як «медіатизація», «медіакратія», «медіацентрована демократія», «медіаполітична система». У тих країнах, які не здатні створити умови для раціонального формування й формулювання суспільно значущої ієрархії проблем буде посилюватись роль власників медіакорпорацій у процесі встановлення порядку денного. I це питання національної безпеки. Справді: «Дослідження ролі масмедіа у політичній інтеракції нині важко уявити без аналізу їх можливостей 3 формування порядку денного. Розгляд цього питання супроводжувався вирішенням багатьох проблем та став основою для розвитку методології дослідження діяльності масмедіа» [8]. М. Мак-Комбс абсолютно правильно відзначає: «Хоча кінцева мета будь-якої політичної кампанії - це перемога в день виборів, свою найближчу ціль кожна 3 них вбачає у стрімкому захопленні медійної програми... На політичну рекламу в масмедіа, переважно телевізійну, в багатьох країнах витрачають величезні суми грошей, оскільки реклама - саме те повідомлення, настанови якого політичні сили воліють бачити серед головних положень громадської думки, але не менші зусилля спрямовані на формування медійної програми, оскільки вона викликає менше підозр у необ'єктивності й зумовлює більшу довіру громадськості» [6, с. 159].

Водночас суспільство має всі необхідні важелі впливу для обмеження ролі медіа у встановленні порядку денного. Вплив медіа закінчується там, де починається повсякденний досвід громадян. Погодимось: «...люди не потребують допомоги 3 боку масмедіа, щоб побачити в інфляції або безробітті серйозну соціальну проблему, бо вони знають про це зі свого безпосереднього досвіду» [8].

Вплив соціальних та політичних мереж на формування публічного порядку денного зростає під час електоральних змагань. Кожна виборча кампанія - це, передусім, спроби кандидатів нав'язати суспільству загалом або своїм цільовим групам необхідний для перемоги порядок денний. У постелекторальний період влада завше реагує лише на ті проблеми порядку денного, які напряму стосуються інтересів великих (молодь, пенсіонери) або впливових соціальних груп (бюрократія, олігархія тощо). Масові протестні рухи в Україні 2004 та 2013-2014 років також пов'язуються із боротьбою за встановлення порядку денного. Ієрархія тут була представлена «злочинною» владою, а мережа - «майданом». Відзначимо: «Зробити суспільні проблеми політичним надбанням може масовий протест, але для цього потрібна організованість і взаємна довіра, особливо довіра до нових лідерів, політичних сил, рухів тощо. 3 позиції сьогоднішнього дня шанси нав'язати свій порядок денний залишаються у всіх. Переможців визначить час, але головне не забувати: хто контролює порядок денний - контролює політику» [1]. I якщо вже для фундаторів теорії порядку денного був очевидним вплив масмедіа на політичну поведінку та політичний (електоральний) вибір індивіда, то для сучасних медіа на наступному етапі розвитку технологій інструментом конструювання штучного порядку денного стали медіаскандали. Цим зумовлене зростання їх кількості у політичному дискурсі напередодні виборів. У медіаскандалах активно використовуються як медіакорпорації, так і соціальні мережі. Внаслідок посилення впливу медіаскандалів на політичний порядок денний відбувається реструктурування політичної реальності на основі інформаційних атак i збудження комунікативного простору. 
Ресурсом для цього володіють лише вертикально підпорядковані політичні ієрархії та медіакорпорації. Це дозволяє окреслити коло осіб, які належать до медіакратії: власники, головні редактори, політичні консультанти та групи PR супроводження політиків. Через те, що всі вони представляють інтереси впливових у пострадянській політиці груп - бюрократії та олігархії у процесі встановлення порядку денного переважає ієрархічний принцип руху інформації («зверху - вниз»).

Висновки. Таким чином, процес встановлення політичного порядку денного охоплює взаємодію влади та опозиції, електоральні змагання та публічне адміністрування, політичні конфлікти та важкі пошуки консенсусу. У ньому віддзеркалюється протистояння суспільного інтересу та приватних інтересів олігархії. Медіа здатні штучно конструювати політичний порядок денний, вони виступають «інформаційними лобістами». Їх вплив на політичний порядок денний зумовлений розвитком технологій та формуванням потужних медіакорпорацій з глобальним впливом. Штучний порядок денний встановлюється завдяки медіаскандалам: спеціально сконструйованим подіям, які викладаються у вигляді динамічної історії, яка привертає увагу аудиторії. У сучасному світі минув період романтичного захоплення соціальними мережами та їх виключно позитивною роллю у встановленні порядку денного. Незважаючи на значний вплив соціальних мереж на початок та розгортання кольорових революцій, у тому числі і в Україні 2004 та 2013-2014 років, нині все більше відчувається їх рух у бік медіакорпорацій, організованих за принципом ієрархії. Зростає роль менеджменту щодо регулювання політичного контенту, широко запроваджується практика блокування користувачів, зокрема й відомих політичних діячів. Цей тренд стає визначальним у встановленні політичного порядку денного у глобальному вимірі.

Обмеженість впливу медіаскандалів зумовлюється зіткненням 3 повсякденним досвідом індивідів. Чим ближча проблема до повсякденного досвіду індивідів, тим менший вплив масмедіа і навпаки. Для протидії процесу медіатизації, який розгортається у відносинах масмедіа, держави та суспільства, і подолання проблеми штучного конструювання політичного порядку денного в Україні запропоновано повернення до раціональних дебатів. Майданчиком для політичних дебатів щодо сутності суспільного інтересу мають стати не масмедіа, а парламент. Саме у стінах вищого представницького органу влади можливий ефективний синтез принципів «ієрархії» та «мережі» у вигляді раціональних парламентських дебатів.

\section{Jimepamypa}

1. Андрусів В. Битва за порядок денний. Українська правда. 2013. 23 січня. URL: https:// www.pravda.com.ua/articles/2013/01/23/6982086/.

2. Дем'янчук О.П. Політична освіта як чинник формування порядку денного публічної політики: теорія та українська практика. Наукові записки: Політичні науки. Київ : Видавничий дім «Києво-Могилянська академія». 2006. Том 57. С. 71-77.

3. Дональд Трамп и его соцсеть: с кем решил потягаться экс-президент CШA. DW. Политика. URL: https://www.dw.com/ru/donald-tramp-i-ego-socset-skem-reshil-potjagatsja-eks-prezident-ssha/a-56951033.

4. Заіка Б., Бровінська М., Шевчук С., Букатюк У . Війна за владу. Чортова дюжина Зеленського. Кого 3 олігархів чекає сюрприз від Президента? Великий список. ЛIГА. Новини. URL: https://biz.liga.net/pervyelitsa/all/article/chertova-dyujina-zelenskogo-kogo-izoligarhov-jdet-syurpriz-ot-prezidenta-bolshoy-spisok.

5. Ковалевський В. Порядок денний: теорія i метод структурування політичної реальності. Наукові записки ІПіЕНД імені І. Кураса НАН України. 2013. Випуск 4 (66). С. $21-224$.

6. Мак-Комбс М. Встановлення пріоритетів: масмедії та громадська думка. Київ : «К. I. С. », 2007. 256 с.

7. Яковлев Д.В. Політичні дебати як засіб раціоналізації політичної взаємодії. Актуальні проблели політики: зб. наук. пр. 2010. Вип. 40. С. 50-57.

8. Яковлев Д.В. Політична взаємодія як комунікативний процес: медіатизація, демократизація, раціоналізація. Одеса : Астропринт, 2009. 288 с.

\section{Анотація}

Лолейко В. І. Політичний порядок денний: «ієрарxiя» vs. «мережа». - Стаття.

У статті досліджується процес формування політичного порядку денного сучасного суспільства. Політичний процес розгортається навколо тем порядку денного. Очевидно, що порядок денний суспільства та окремих впливових груп (бюрократії, олігархії, медіакратії тощо) не завжди співпадає. Адже ресурси цих груп дозволяють маніпулювати порядком денним задля вилучення суспільного інтересу з політичного дискурсу та підміни його приватними інтересами у процесі визначення рейтингу соціальних та політичних проблем. Визначено, що політичний порядок денний є публічним, а на його встановлення впливають ієрархії, засновані на вертикальних зв’язках та мережі, які характеризуються горизонтальними відносинами. Встановлення політичного порядку денного відбувається на перетині взаємодії влади та опозиції, електоральних змагань та публічного адміністрування, політичних конфліктів та пошуків консенсусу. На політичний порядок денний впливають повсякденний досвід індивідів, дії політиків та державних діячів. Чим ближча проблема до повсякденного досвіду індивідів, тим менший вплив масмедіа і навпаки. Медіа здатні штучно конструювати політичний порядок денний, вони виступають «інформаційними лобістами». Ïх вплив на політичний порядок денний зумовлений розвитком технологій та формуванням потужних медіакорпорацій з глобальним впливом. Штучний порядок 
денний встановлюється завдяки медіаскандалам: спеціально сконструйованим подіям, які викладаються у вигляді динамічної історії, яка привертає увагу аудитоpiï. Наголошено на необхідності протидії процесу медіатизації, який розгортається у відносинах масмедіа, держави та суспільства. Як відповідь на виклики медіатизації та подолання проблеми штучного конструювання політичного порядку денного запропоновано повернення до раціональних дебатів. Майданчиком для політичних дебатів щодо сутності суспільного інтересу мають стати не масмедіа, а парламент. Саме у стінах вищого представницького органу влади можливий ефективний синтез принципів «ієрархії» та «мережі» у вигляді раціональних парламентських дебатів.

У медіапросторі також відбувається протиставлення вертикально підпорядкованих медіакорпорацій («ієрархій») та Інтернет-медіа (передусім, соціальних мереж).

Відзначено, що у сучасному світі минув період романтичного захоплення соціальними мережами та їх виключно позитивною роллю у встановленні порядку денного. Незважаючи на значний вплив соціальних мереж на початок та розгортання кольорових революцій, у тому числі і в Україні 2004 та 2013-2014 років, нині все більше відчувається їх рух у бік медіакорпорацій, організованих за принципом ієрархії. Зростає роль менеджменту щодо регулювання політичного контенту, широко запроваджується практика блокування користувачів, зокрема й відомих політичних діячів. Цей тренд стає визначальним у встановленні політичного порядку денного у глобальному вимірі.

Ключові слова: порядок денний, політичний процес, ієрархія, мережа, політичний порядок денний, теорія настановчості, публічна політика, медіакратія.

\section{Summary}

Lomeiko V. I. Political agenda: "hierarchy" vs. "network". - Article.

The article examines the process of forming the political agenda of modern society. The political process revolves around the topics on the agenda. It is obvious that the agenda of society and certain influential groups (bureaucracy, oligarchy, mediacracy, etc.) does not always coincide. The resources of these groups allow manipulating the agenda in order to remove the public interest from political discourse and replace it with private interests in the process of determining the rating of social and political problems. The political agenda is defined as public, and its establishment is influenced by hierarchies based on vertical links and networks characterized by horizontal relations. The political agenda is set at the intersection of government and opposition, electoral competition and public administration, political conflicts and consensus-seeking. The political agenda is influenced by the daily experience of individuals, the actions of politicians and statesmen. The closer the problem to the everyday experience of individuals is, the less the influence of the media is and vice versa. The media are able to artificially construct the political agenda; they act as "information lobbyists". Their influence on the political agenda is due to the development of technology and the formation of powerful media corporations with global influence. The artificial agenda is set by media scandals: specially designed events that are presented in the form of a dynamic story that attracts the audience's attention. The necessity to counteract the process of mediatization, which is unfolding in the relations between the media, the state and society is emphasized. In response to the challenges of mediatization and overcoming the problem of artificial construction of a political agenda, a return to rational debate is proposed. The platform for political debate on the essence of the public interest should be not the media, but the parliament. It is within the walls of the highest representative body of power that an effective synthesis of the principles of "hierarchy" and "network" in the form of rational parliamentary debates is possible. In the media space, there is also a contrast between vertically subordinat ed media corporations ("hierarchies") and Internet media (primarily, social networks). It is noted that in the modern world the period of romantic fascination with social networks and their exclusively positive role in setting the agenda has passed. Despite the significant influence of social networks on the beginning and unfolding of colour revolutions, including Ukraine in 2004 and 2013-2014, today their movement towards media corporations organized on the principle of hierarchy is increasingly felt. The role of management in regulating political content is growing, and the practice of blocking users, including well-known politicians, is being widely introduced. This trend is becoming decisive in setting the political agenda in the global dimension.

Key words: agenda, political process, hierarchy, network, public policy, mediacracy. 